УДК 342.9

DOI https://doi.org/10.32837/apdp.v0i87.2819

А. М. Чорна

\title{
ДО ХАРАКТЕРИСТИКИ ПРАВОВОГО СТАТУСУ ОКРЕМИХ ЦЕНТРАЛЬНИХ ОРГАНІВ ВИКОНАВЧОЇ ВЛАДИ ЯК СУБ'ЄКТІВ ЗАБЕЗПЕЧЕННЯ ПРАВ СУБ'СКТІВ ПІДПРИЄМНИЦЬКОЇ ДІЯЛЬНОСТІ
}

Постановка проблеми. Роль підприємницької діяльності для держави та суспільства складно переоцінити, адже вона має суттєвий вплив на всі сфери суспільного життя. Так, з економічної точки зору підприємницька діяльність сприяє залученню великих грошових коштів у різні галузі господарства, що сприяє розвитку національної економіки в цілому. Активні учасники підприємницької діяльності є найбільшими й основними платниками податків. Не можна не відмітити й соціальний ефект підприємництва, оскільки широка мережа малих і середніх підприємств сприяє створенню робочих місць. Підприємництво в суспільстві так само необхідне, як і в економіці; в установах сфери обслуговування - так само, як на промислових підприємствах. А тому важливим завданням держави є створити всі необхідні умови для забезпечення прав суб'єктів підприємницької діяльності. Досягти останнього, на нашу думку, неможливо без належного функціонування відповідних суб'єктів.

Стан дослідження. Прямо чи опосередковано адміністративно-правовий статус тих чи інших суб'єктів різних галузей права досліджували: С.С. Алєксєєв, М.Г. Александров, М.В. Вітрук, Ю.С. Гамбаров, Н.П. Журавльова, Р.І. Кондратьєв, О.В. Кохановська, О.О. Красавчиков, І.М. Кучеренко, М.С. Малеїн, О.П. Орлюк, P.О. Стефанчук, Є.О. Суханов, В.О. Тархов, Ю.Г. Ткаченко, Г.Ф. Шершеневич та інші. Однак і дотепер не отримало свого комплексного дослідження питання адміністративно-правового статусу суб'єктів забезпечення прав суб'єктів підприємницької діяльності у сфері оподаткування.

Мета статті - надати характеристику правовому статусу окремих центральних органів виконавчої влади як суб’єктів забезпечення прав суб'єктів підприємницької діяльності.

Виклад основного матеріалу. Починаючи наукове дослідження, слід вказати, що особливе місце серед суб'єктів забезпечення прав суб'єктів підприємницької діяльності у сфері оподаткування посідають органи виконавчої влади на чолі з Кабінетом Міністрів України. Так, як встановлено в ст. 113 Конституції України, Кабінет Міністрів України є вищим органом у системі органів виконавчої влади. Він є відповідальним перед Президентом України та Верховною Радою України, підконтрольний та підзвітній останній [1]. Більш детально правовий статус Кабінету Міністрів України регламентовано в положеннях Закону України «Про Кабінет Міністрів України». Так, у ст. 20 вищенаведеного нормативно-правового акта встановлено основні повноваження Кабінету Міністрів України в різних сферах суспільного життя. Комплексний аналіз зазначених законодавчих положень надав змогу виокремити ті з повноважень Кабінету Міністрів України, які в повній 
мірі характеризують його як суб'єкта забезпечення прав суб'єктів підприємницької діяльності. Серед таких повноважень слід назвати такі: забезпечує проведення державної економічної політики, здійснює прогнозування та державне регулювання національної економіки; забезпечує розроблення і виконання загальнодержавних програм економічного та соціального розвитку; сприяє розвитку підприємництва на засадах рівності перед законом усіх форм власності та соціальній спрямованості національної економіки, здійснює заходи щодо демонополізації та антимонопольного регулювання економіки, розвитку конкуренції та ринкової інфраструктури; забезпечує здійснення державної регуляторної політики у сфері господарської діяльності; забезпечує розроблення і виконання програм структурної перебудови галузей національної економіки та інноваційного розвитку, здійснює заходи, пов'язані з реструктуризацією та санацією підприємств і організацій, забезпечує проведення державної промислової політики, визначає пріоритетні галузі промисловості, які потребують прискореного розвитку [2], тощо. Окрім вищенаведеного, слід зазначити, що так само, як і вказані вище суб'єкти, Кабінет Міністрів України здійснює регулюючий вплив на правовідносини з приводу забезпечення прав суб'єктів підприємницької діяльності шляхом видання відповідних правових актів. Так, як слідує з аналізу ст. 49 (акти Кабінету Міністрів України) Закону України «Про Кабінет Міністрів України», Кабінет Міністрів України на основі та на виконання Конституції і законів України, актів Президента України, постанов Верховної Ради України, прийнятих відповідно до Конституції та законів України, видає обов'язкові для виконання акти - постанови і розпорядження. Постановами Кабінету Міністрів України є акти нормативного характеру, а розпорядженнями - акти з організаційно-розпорядчих та інших поточних питань [2].

Отже, як окремий вид суб'єктів забезпечення прав суб'єктів підприємницької діяльності у сфері оподаткування слід розглядати Кабінет Міністрів України. Адміністративно-правовий статус даного суб'єкта зумовлений декількома особливостями: він є вищим органом виконавчої влади, а тому координує та контролює діяльність усіх інших підпорядкованих йому органів у досліджуваному напрямі; він наділений широким колом повноважень у досліджуваній сфері; здійснює правове регулювання суспільних відносин, пов'язаних із забезпеченням прав суб'єктів підприємницької діяльності у сфері оподаткування.

Слід зазначити, що, діючи як суб'єкт забезпечення прав суб'єктів підприємницької діяльності у сфері оподаткування, Кабінет Міністрів України реалізує свої повноваження як безпосередньо, так і через інші органи державної виконавчої влади. Зокрема, відповідно до ч. 2 ст. 1 Закону України «Про Кабінет Міністрів України» Кабінет Міністрів України здійснює виконавчу владу безпосередньо та через міністерства, інші центральні органи виконавчої влади, Раду міністрів Автономної Республіки Крим та місцеві державні адміністрації, спрямовує, координує та контролює діяльність цих органів [2]. А тому як окремі види досліджуваних суб'єктів слід розглядати наведені вище органи виконавчої влади. Здійснимо характеристику особливостей адміністративно-правового статусу окремих з таких суб'єктів, функціонування яких має безпосереднє відношення до забезпечення прав суб’єктів підприємницької діяльності у сфері оподаткування. 
Представниками першої групи зазначених суб'єктів є центральні органи виконавчої влади. Правовий статус таких суб'єктів, організацію, повноваження та порядок їхньої діяльності встановлено на рівні Закону України «Про центральні органи виконавчої влади» від 13 березня 2011 року. Відповідно до ст. 1 вищенаведеного нормативно-правового акта систему центральних органів виконавчої влади становлять міністерства України та інші центральні органи виконавчої влади. При цьому міністерства забезпечують формування та реалізують державну політику в одній чи декількох сферах, інші центральні органи виконавчої влади виконують окремі функції з реалізації державної політики. Повноваження міністерств, інших центральних органів виконавчої влади поширюються на всю територію держави [3]. Шляхом аналізу наведених законодавчих положень можна дійти певних висновків, які можуть бути використані для позначення особливостей адміністративно-правового статусу центральних органів виконавчої влади: 1) будучи цілісним державним утворенням, вони складаються з міністерств та інших центральних органів виконавчої влади; 2) вони є загальнодержавними суб'єктами, оскільки їхні повноваження не обмежуються окремо взятою адміністративно-територіальною одиницею, а поширюються на всю без виключення територію нашої держави; 3) однак такі повноваження мають чітку спрямованість і направлені на врегулювання однієї чи декількох споріднених сфер суспільного життя. 3 урахуванням наведених вище особливостей адміністративно-правового статусу центральних органів виконавчої влади повинні бути названі ті з них, які належать до суб'єктів забезпечення прав суб'єктів підприємницької діяльності у сфері оподаткування.

Як слідує з аналізу положень Закону України «Про центральні органи виконавчої влади», міністерство є центральним органом виконавчої влади, який забезпечує формування та реалізує державну політику в одній чи декількох визначених Кабінетом Міністрів України сферах, проведення якої покладено на Кабінет Міністрів України Конституцією та законами України. Основними завданнями міністерства як органу, що забезпечує формування та реалізує державну політику в одній чи декількох сферах, є: забезпечення нормативно-правового регулювання; визначення пріоритетних напрямів розвитку; інформування та надання роз'яснень щодо здійснення державної політики; узагальнення практики застосування законодавства, розроблення пропозицій щодо його вдосконалення та внесення в установленому порядку проектів законодавчих актів, актів Президента України, Кабінету Міністрів України на розгляд Президентові України та Кабінету Міністрів України; забезпечення здійснення соціального діалогу на галузевому рівні; здійснення інших завдань, визначених законами України [3]. 3 аналізу Схеми спрямування і координації діяльності центральних органів виконавчої влади Кабінетом Міністрів України через відповідних членів Кабінету Міністрів України, що затверджена постановою Кабінету Міністрів України від 10 вересня 2014 року № 442 слідує, що сьогодні функціонує велика кількість міністерств. 3 огляду на особливості їхнього адміністративно-правового статусу як суб’єктів забезпечення прав суб'єктів підприємницької діяльності у сфері оподаткування нами розглядаються такі міністерства: 
1) Міністерство внутрішніх справ України, яке відповідно до положення «Про Міністерство внутрішніх справ України», що затверджене постановою Кабінету Міністрів України від 28 жовтня 2015 року № 878, є головним органом у системі центральних органів виконавчої влади, який забезпечує формування державної політики у сфері забезпечення прав і свобод людини, інтересів суспільства й держави, протидії злочинності, підтримання публічної безпеки і порядку, а також надання поліцейських послуг [4];

2) Міністерство аграрної політики та продовольства, яке відповідно до Положення «Про Міністерство аграрної політики та продовольства», затвердженого постановою Кабінету Міністрів України від 25 листопада 2015 року № 1119, є головним органом у системі центральних органів виконавчої влади, що забезпечує: формування та реалізацію державної аграрної політики, державну політику у сферах сільського господарства та з питань продовольчої безпеки держави [5];

Особливості адміністративно-правового статусу наведених вище міністерств полягають у тому, що вони реалізують повноваження, направлені на охорону та захист суспільних відносин із приводу підприємницької діяльності. Окрім цього, вони формують та забезпечують реалізацію державної політики в галузях, що пов’язані зі здійсненням підприємницької діяльності, а саме це паливно-енергетичні комплекси, сільське господарство, нагляд та контроль за господарською діяльністю тощо. Проте міністерством, до основних завдань якого належить забезпечення прав суб'єктів підприємницької діяльності, є Міністерство фінансів України. Відповідно до Положення «Про Міністерство фінансів України», затвердженого постановою Кабінету Міністрів України від 20 вересня 2014 року № 375, Міністерство фінансів України є головним органом у системі центральних органів виконавчої влади, що забезпечує формування та реалізує державну фінансову та бюджетну політику, державну політику у сфері державного пробірного контролю, бухгалтерського обліку, випуску і проведення лотерей, а також забезпечує формування та реалізацію державної політики у сфері контролю за дотриманням бюджетного законодавства, державного внутрішнього фінансового контролю, казначейського обслуговування бюджетних коштів, запобігання і протидії легалізації (відмиванню) доходів, одержаних злочинним шляхом, або фінансуванню тероризму, забезпечує формування державної політики у сфері організації та контролю за виготовленням цінних паперів, документів суворої звітності та забезпечує формування та реалізацію єдиної державної податкової, митної політики, державної політики з адміністрування єдиного внеску на загальнообов'язкове державне соціальне страхування, державної політики у сфері боротьби з правопорушеннями під час застосування податкового та митного законодавства, а також законодавства з питань сплати єдиного внеску, державної політики у сфері видобутку, виробництва, використання та зберігання дорогоцінних металів і дорогоцінного каміння, дорогоцінного каміння органогенного утворення та напівдорогоцінного каміння, їх обігу та обліку [6]. Аналіз наведених вище завдань Міністерства фінансів України свідчить про його першорядну роль в аспекті забезпечення прав суб'єктів підприємницької діяльності у сфері оподаткування. 
Говорячи про інші центральні органи виконавчої влади як суб'єктів забезпечення прав суб’єктів підприємницької діяльності у сфері оподаткування, слід зазначити, що особливості їхнього адміністративно-правового статусу будуть, окрім іншого, знаходити свій прояв у назві відповідного органу. У даному випадку йдеться, що такі суб'єкти відповідно до приписів чинного національного законодавства можуть утворюватися як служби, інспекції або агентства. При цьому назва відповідного суб'єкта буде мати свій прямий вплив на його функціональне призначення. Зокрема, з аналізу Розділу III «Інші центральні органи виконавчої влади» Закону України «Про центральні органи виконавчої влади» слідує, що створюється орган виконавчої влади, більшість функцій якого пов'язана з наданням адміністративних послуг фізичним особам. У свою чергу як інспекція центральний орган виконавчої влади створюється, якщо більшість його функцій є контрольно-наглядовими за дотриманням органами державної влади, органами місцевого самоврядування, їхніми посадовими особами, юридичними та фізичними особами актів законодавства. Насамкінець, як агентство центральний орган виконавчої влади створюються в разі, якщо більшість із його функцій пов'язані з управлінням державною власністю [2].

Станом натепер функціонує велика кількість служб, інспекцій та агентств. У контексті досліджуваного питання найбільший інтерес для нас представляють такі центральні органи виконавчої влади, як служби. Серед них як суб'єкта забезпечення прав суб'єктів підприємницької діяльності у сфері оподаткування слід розглядати Державну аудиторську службу України, яка діє відповідно до положення «Про державну аудиторську службу України», затвердженого постановою Кабінету Міністрів України від 3 лютого 2016 року № 43. Відповідно до положення Служба є центральним органом виконавчої влади, що забезпечує формування і реалізує державну політику у сфері державного фінансового контролю [7];

Окремо слід згадати такого провідного суб'єкта забезпечення прав суб'єктів підприємницької діяльності, як Державна податкова служба (далі - ДПС). ДПС $\epsilon$ центральним органом виконавчої влади, діяльність якого спрямовується і координується Кабінетом Міністрів України через Міністра фінансів, і який реалізує державну податкову політику, державну політику з адміністрування єдиного внеску на загальнообов'язкове державне соціальне страхування. Основними завданнями ДПС є: 1) реалізація державної податкової політики, здійснення в межах повноважень, передбачених законом, контролю за надходженням до бюджетів та державних цільових фондів податків, зборів, платежів, державної політики у сфері контролю за виробництвом та обігом спирту, алкогольних напоїв, тютюнових виробів, пального, державної політики з адміністрування єдиного внеску, державної політики у сфері контролю за своєчасністю здійснення розрахунків в іноземній валюті в установлений законом строк, дотриманням порядку проведення готівкових розрахунків за товари (послуги), проведення розрахункових операцій, а також за наявністю ліцензій на провадження видів господарської діяльності, що підлягають ліцензуванню відповідно до закону; 2) внесення на розгляд Міністра фінансів пропозицій щодо забезпечення формування: державної податкової політики; здійснення контролю за надходженням до бюджетів та державних цільових 
фондів податків, зборів, платежів; державної політики у сфері контролю за виробництвом та обігом спирту, алкогольних напоїв, тютюнових виробів, пального; державної політики з адміністрування єдиного внеску, а також у сфері боротьби з правопорушеннями під час застосування законодавства з питань сплати єдиного внеску; державної політики у сфері контролю за своєчасністю здійснення розрахунків в іноземній валюті в установлений законом строк, дотриманням порядку проведення готівкових розрахунків за товари (послуги), проведення розрахункових операцій, а також за наявністю ліцензій на провадження видів господарської діяльності, що підлягають ліцензуванню відповідно до закону.

Висновок. Таким чином, центральні органи виконавчої влади, набуваючи адміністративно-правового статусу суб'єктів забезпечення прав суб'єктів підприємницької діяльності, реалізують свої повноваження шляхом забезпечення формування та реалізації державної політики, а також окремі функції з реалізації державної політики у вказаному спрямуванні. Серед особливостей їхнього адміністративно-правового статусу слід назвати те, що: вони є представниками державної виконавчої влади; їхня компетенція поширюється на всю територію України; їхня назва залежить від їх функціонального призначення; вони наділені широким комплексом повноважень, спрямованих на забезпечення прав суб'єктів підприємницької діяльності у сфері оподаткування.

\section{Jimepamypa}

1. Конституція України : Закон України від 28.06.1996 р. № 254к/96-ВР. Відомості Верховної Ради України. 1996. № 30. Ст. 141.

2. Про Кабінет Міністрів України : Закон України : від 27 лют. 2014 р. № 794-VII. Відомості Верховної Ради України. 2014. № 22. Ст. 222.

3. Про центральні органи виконавчої влади : Закон України від 17 бер. 2011 р. № 3166-VI. Oфiuіŭний вісник України. 2011. № 27. Ст. 1123.

4. Про затвердження Положення про Міністерство внутрішніх справ України : Постанова Кабінету Міністрів України від 28 жовт. 2015 р. № 878. Офіційний вісник України. 2015. № 89. Ст. 2972.

5. Про затвердження Положення про Міністерство аграрної політики та продовольства України : постанова Кабінету Міністрів України від 25 лист. 2015 р. № 1119. Офіційний вісник України. 2016. № 2. Ст. 68.

6. Про затвердження Положення про Міністерство фінансів України : постанова Кабінету Міністрів України від 20 серп. 2014 р. № 375. Офіційний вісник України. 2014. № 69. Ст. 1936. URL: http://zakon2.rada.gov.ua/laws/show/375-2014-п.

7. Про затвердження Положення про Державну аудиторську службу України : Постанова Кабінету Міністрів України ; Положення від 03.02.2016 р. № 43. URL: https://zakon.rada.gov.ua/laws/ show/43-2016-п.

\section{Анотація}

Чорна А. М. До характеристики правового статусу окремих центральних органів виконавчої влади як суб̆'єктів забезпечення прав суб’єктів підприємницької діяльності. - Стаття.

Актуальність статті полягає в тому, що роль підприємницької діяльності для держави та суспільства складно переоцінити, адже вона має суттєвий вплив на всі сфери суспільного життя. Так, з економічної точки зору підприємницька діяльність сприяє залученню великих грошових коштів у різні галузі господарства, що сприяє розвитку національної економіки в цілому. Активні учасники підприємницької діяльності є найбільшими і основними платниками податків. Не можна не відмітити й соціальний ефект підприємництва, оскільки широка мережа малих і середніх підприємств сприяе створенню робочих місць. Підприємництво в суспільстві так само необхідне, як і в економіці; в устано- 
вах сфери обслуговування - так само, як на промислових підприємствах. А тому важливим завданням держави є створити всі необхідні умови для забезпечення прав суб'єктів підприємницької діяльності. У статті на основі аналізу наукових поглядів учених та норм чинного законодавства України надано характеристику правового статусу окремих центральних органів виконавчої влади як суб'єктів забезпечення прав суб'єктів підприємницької діяльності. Наголошено, що як окремий вид суб'єктів забезпечення прав суб'єктів підприємницької діяльності у сфері оподаткування слід розглядати Кабінет Міністрів України. Адміністративно-правовий статус даного суб'єкта зумовлений декількома особливостями: він є вищим органом виконавчої влади, а тому координує та контролює діяльність усіх інших підпорядкованих йому органів у досліджуваному напрямі; він наділений широким колом повноважень у досліджуваній сфері; здійснює правове регулювання суспільних відносин, пов'язаних із забезпеченням прав суб'єктів підприємницької діяльності у сфері оподаткування. Узагальнено, що центральні органи виконавчої влади, набуваючи адміністративно-правового статусу суб'єктів забезпечення прав суб'єктів підприємницької діяльності, реалізують свої повноваження шляхом забезпечення формування та реалізації державної політики, а також окремі функції з реалізації державної політики у вказаному спрямуванні. Серед особливостей їхнього адміністративно-правового статусу слід назвати те, що: вони є представниками державної виконавчої влади; їхня компетенція поширюється на всю територію України; їхня назва залежить від їх функціонального призначення; вони наділені широким комплексом повноважень, спрямованих на забезпечення прав суб'єктів підприємницької діяльності у сфері оподаткування.

Ключові слова: правовий статус, центральні органи виконавчої влади, суб'єкт, права, підприємницька діяльність.

\section{Summary}

Chorna $A . M$. On the characteristics of the legal status of individual central executive bodies as the subjects guaranteeing the rights of business entities. - Article.

The relevance of the article is that the role of entrepreneurial activity for the state and society is difficult to overestimate, because it has a significant impact on all spheres of public life. Thus, from an economic point of view, entrepreneurial activity contributes to attracting large sums of money in various sectors of the economy, which contributes to the development of the national economy as a whole. Active business participants are the largest and main taxpayers. It is necessary to note the social effect of entrepreneurship, as a wide network of small and medium enterprises contributes to job creation. "Entrepreneurship in society is just as necessary as in the economy; in institutions of the service sector - as well as in industrial enterprises. Therefore, the important task of the state is to create all the necessary conditions to ensure the rights of business entities. The article, based on an analysis of scientific views of scientists and current legislation of Ukraine, provides a description of the legal status of individual central executive bodies as subjects of ensuring the rights of business entities. It was emphasized that the Cabinet of Ministers of Ukraine should be considered as a separate type of subjects for ensuring the rights of business entities in the field of taxation. The administrative and legal status of this entity is due to several features: it is the highest body of executive power, and therefore coordinates and controls the activities of all other bodies subordinate to him in the study area; he is endowed with a wide range of powers in the research area; carries out legal regulation of public relations related to ensuring the rights of business entities in the field of taxation. It is generalized that the central executive bodies, acquiring the administrative and legal status of the subjects of ensuring the rights of business entities, exercise their powers by ensuring the formation and implementation of state policy, as well as certain functions of implementing state policy in this direction. Among the features of their administrative and legal status should be mentioned that: they are representatives of the state executive power; their competence extends to the entire territory of Ukraine; their name depends on their functional purpose; endowed with a wide range of powers aimed at ensuring the rights of business entities in the field of taxation.

Key words: legal status, central executive bodies, subject, rights, entrepreneurial activity. 